\title{
A View from the 50th Street Gate on Washington Avenue: Reflections of a Working-Class Academic
}

\author{
Heather Wyatt-Nichol \\ University of Baltimore College of Public Affairs
}

\begin{abstract}
This manuscript offers a firsthand account of obstacles I experienced as a working-class, first-generation college student and how my origins still affect my thoughts and actions as a professor of Public Administration. In this context, I consider larger issues of social class in admissions and the overall college experience, including proposing strategies to help students, especially those whose backgrounds are similar to mine, to maximize their odds of finishing their degrees. The manuscript ends by proposing that our field begin placing more emphasis on understanding social class inequalities.
\end{abstract}

\section{WorkING-Class RoOTs}

My paternal grandparents were born in the late 1920s and grew up in the Appalachian Mountains near what is now the Blue Ridge Parkway in North Carolina. My grandmother was born in a log house her father built before marrying her mom. My grandmother was the youngest of 13 brothers and sisters. I visited my great-uncle at this log house on the mountain several times before it burned in 1979. Neither grandparent grew up with electricity. My grandfather often told of his return home from service after World War II to find, to his surprise, the homes on the mountain had electricity. My grandmother told me some families on the mountain cut the lines intended for electricity, took them home, put them in their yards, and used them for hanging clothes to dry.

My maternal grandparents were also born in the late 1920s and grew up in Thomasville, North Carolina - the original home of Thomasville Furniture before the company relocated to China. Both grandfathers moved to Newport News, Virginia, between the late 1940s and early 1950s to work at Newport News Shipbuilding. The shipyard constructs a variety of vessels including aircraft 
carriers and submarines for the U.S. Navy. My grandfathers were part of a larger migration of men in the western regions of North Carolina and Virginia who relocated to work in the Newport News Shipyard. Today, it is customary to meet individuals along the Virginia coast whose families moved from the southwestern regions of North Carolina and Virginia. The stories my paternal grandmother shared illustrate just how isolated her home in the mountains was compared to the port city of Newport News. Every Thanksgiving we laugh about her recollection of cooking her first turkey—on a stovetop! Despite there being wild turkeys all over the North Carolina Mountains, it was never on the menu at her house. I am also amused when she tells of being struck by fear the first time she saw a nun in full garb. Obviously, there were not any Catholic churches in her neck of the woods. Regardless, both sets of grandparents acclimated to their new environment, and both grandfathers made a reasonable living over the years.

My parents met in high school in the mid-to-late 1960s. My mother served as an art editor for the school newspaper and worked at the city library after school. My father held a variety of jobs - newspaper boy, sanitation worker, and carpenter. My mother graduated in 1968; however, my father never finished high school. They married shortly before my birth.

Living near a port has its disadvantages - the drug trade. Anyone with keen observational skills who has ever lived in a port city along the East or West coast knows heroin is readily available. My father was a heroin addict. At some point, he started selling heroin to support his habit. He was arrested twice for heroin distribution. During his second incarceration, his parents would not post bail. They thought he might "learn his lesson" in jail awaiting trial. Instead, he hanged himself-he was only 19 years old. He received no medical treatment or spiritual counseling. Methadone was not provided in the jails during this time. A letter to the editor in the local newspaper called for an active role of the clergy in city jails. Today, it would be considered cruel and unusual punishment to deny methadone to an incarcerated heroin addict. Clergy are also active in jails and prisons, where they provide spiritual counseling and rehabilitative programs.

My mother was only 21 years old when my father passed away. Although it was common in the early 1970s for women to either remarry or receive government assistance, she sought work that paid a living wage to support us both. Luckily for her, in 1972 the Maritime Administration required private shipyards with government contracts to develop affirmative action plans to address the underrepresentation of women and minorities in this field (Clynch \& Gaudin, 1982). The good-paying shipyard jobs were "on the water"-blue-collar, skilled labor positions men usually held. My mother submitted applications every month until she was hired to be trained as a welder/shipfitter.

One of my very first memories is of standing on our balcony at the apartments looking at the crane and production shops across the street at the shipyard. The crane was among the largest in the world at 20 stories high, 
gargantuan compared to my small stature. Nevertheless, I knew little about the magnitude of production - only that my mother worked there. While she was at work, I spent my hours at a church-run day care and preschool program in the east end of Newport News. This is where I learned to hit back. There were a few kids who sometimes picked on me. Whenever I went crying to the teacher, she told me to hit back-advice never doled out today. Nevertheless, in working-class communities an individual gains respect when he or she confronts an individual who initiates a challenge or threat. The fact I was the only white girl in the program highlights the relevance of both social class and race.

While middle-class women were becoming empowered through employment during the second-wave feminist era of the 1960s and 1970s, a large share of working-class minority women were employed outside the home in positions ranging from domestic servants to factory production workers- the result of discrimination and economic necessity.

\section{The Road to College: Why They Are Called Classrooms}

During my many years of formal education, I was never exposed to the wealth of research showing that lower-income and working-class children are far less likely to attend college than children of middle- to upper-class parents. Schools are not in the business of raising class consciousness, notwithstanding their role in perpetuating the class system. Likewise, I did not know that the type of college or university people attend closely correlates with their social class origins. For example, few working-class and low-income students attend the country's elite universities (Aronowitz, 2004; Oldfield, Candler, \& Johnson, 2006; Raines \& McAdams, 2006).

"Concerted cultivation" (Bourdieu, 1989) describes parenting tactics aimed at childhood development within the long-term strategy of raising a youngster's odds of getting into a top college. Concerted cultivation did not exist in my household. My mother did not have money to buy me ballet lessons, music instruction, and other "valued" cultural learning that would greatly improve my social mobility odds. When she arrived home, she was too tired to participate in activities such as PTA or serve as a Girl Scout troop leader. Who could blame her? Her job was physically demanding, and she had to endure all those sweltering summers and frigid winters.

As a widow, my mother received $\$ 165.00$ a month in supplemental security income (SSI) through the Social Security Administration. During the Reagan administration, she received a letter saying her SSI might be reduced or eliminated. I was 15 years of age, and she informed me I should find work. My first job was summer employment as a clerk at a video store. The location was a 45-minute bus ride away; and once school started, I began looking for work closer to home. That October, I took a job as a waitress at an old-fashioned lunch counter diner in a pharmacy. I worked there for 7 years, beginning in high 
school and running through college. I want to believe work did not interfere with my high school grades; although, for sure, it greatly hindered my ability to engage in extracurricular activities. I was not in band, did not play sports, and did not belong to any higher-status clubs—all the things colleges look for on an admissions application. The only activity I had time for was serving as local treasurer of the Vocational Industrial Clubs of America (VICA). VICA is typically placed in vocational schools; however, our high school included skills training programs. To privilege extracurricular activities that require a significant amount of otherwise leisure time places working-class applicants at a significant disadvantage in the college admissions process.

My winding road to higher education proves my lack of concerted cultivation. My high school guidance counselor tried to steer me toward vocational school or ROTC. His intentions were not surprising, given my social class origins and behavioral problems in junior high. This is the kind of "career advice" counselors gave "bad" kids. Nevertheless, my mother was convinced I should further my education. Years of grinding work in the shipyard strengthened her conviction that I should have a better future. She threatened to kill me if I went to work in the shipyard. As you might expect, she was not familiar with the college admissions process. I was completely unprepared for college night. Our city school system held college night at the coliseum convention center and invited recruiters to distribute material about their institutions and collect information from potential applicants. Although I had good grades, I did not know my grade point average. More precisely, I did not know the typical scale of 4.0 for a grade point average. Moreover, I knew I had to take the SAT, but had no idea how important it was in the admissions process or that your scores closely correlate with your family's income and parental education (see http://fairtest.org). I did not attend any KAPLAN seminars or study sessions to prepare for my SAT. I do not recall my scores; however, I imagine they were sufficient to get me rejected from the top schools where had I applied.

During my senior year of high school my "stepfather" at the time fell in love with a young woman my age. He was functionally illiterate, told me he would not contribute "one red penny" toward my college education, and kicked my mother and me out of the house. Because they were not legally married and Virginia does not recognize common law marriages, she had no legal recourse. My mother had neither claim to the house nor any means to be compensated for the time and money she had invested in their relationship over the years. Consequently, she had to file bankruptcy. The financial stress, coupled with her severe depression at the time, led me to select a school within driving distance without residency requirements. Given the personal demands of working-class students, it is not surprising many are commuters. 


\section{The College Years}

I attended Christopher Newport University, a small, public, liberal arts college in Newport News, Virginia that, at the time, served mostly working students from the region. Although I made a couple of friends during college, I spent most of my time with friends who did not pursue higher education. Likewise, I was too busy attending classes full-time and working full-time to engage in extracurricular activities or go to campus events. I have never participated in the annual spring break ritual of many college students-I did not have vacation time or money to spend on Florida beaches. Nevertheless, as a political science major, I volunteered for a local congressional campaign. I took Vivarin, the caffeine energy aid, every day to sustain my energy levels at school and work. I stayed up countless nights completing papers on my Silver Reed typewriter. This was before the Internet, when one had to visit the library and photocopy information, so I ended up spending hundreds of dollars photocopying materials to use for my senior project. During my senior year of college, I applied to only two schools, both Ivy League. One was a top graduate school in political science and the other a top law school. I thought grades alone were sufficient and that my GPA would get me accepted at either place-I graduated with honors. Once again, however, I did not prepare for the required standardized tests and lacked any extracurricular activities to dazzle the admissions committees.

My future was uncertain. I felt like a deer in the headlights_-stunned and unsure which direction to take. A liberal arts degree in political science was not very marketable during a recession; however, I felt compelled to leave my waitressing job even if it meant a short stint of unemployment. Luckily, a friend who worked for the Spiegel group (a Fortune 500 company with unlimited opportunities at the time) helped me land a job in their customer service department. The organization had offices across the United States and globally. There were training departments, marketing departments, sales departments, accounts, legal and human resource departments, and so on. The organization paid a good wage, provided promotion opportunities, and had good 401(k) options. Although the job was unrelated to my degree, it was an attractive place to work for a while.

After a couple of years working at the Spiegel Group, I enrolled in the MPA program at Old Dominion University in Norfolk, Virginia. Three factors led to this choice. First, I was getting bored with my job-despite their employment enrichment efforts. Second, I felt I was not making a difference in society. Third, a cost-benefit analysis of pursuing teacher certification or earning a master's degree led me to the MPA. Moreover, The MPA offered a marketable skill set for public service.

Not surprisingly, I ran into obstacles during my first semester in the MPA program. I still resided in the Hampton Roads area; however, I intended to 
move back home with my mother and convert to a part-time work schedule so I could concentrate on my studies. I did not renew the apartment lease with my roommates and placed my items in storage. During this time, I had a "falling out" with my mother. For reasons too numerous to offer here, I chose to leave. A childhood friend took me in for a couple of months until I saved enough for a studio apartment. As soon as I moved into the apartment, the transmission went out in my car. Murphy's Law was working overtime for me.

\section{THE Work World, POST-MPA}

Upon earning my MPA at Old Dominion University, I started working for the United Way in a temporary fund-raising position. Shortly thereafter, I worked as a research technician/program coordinator in a leadership-training program for local law enforcement. This was a 4-year funded position through an Edward Byrne Memorial Fund grant issued by the Office of Justice Programs at the U.S. Department of Justice. The grant is named after a New York City police officer, Edward Byrne, who was gunned down by drug dealers shortly before he was scheduled to testify against them in court.

One must recognize the irony of this position for me, considering my father's circumstances. In looking back, I know this job dramatically affected where I am today. I had a choice of offices - either on-campus or at police headquarters. Having had an office through an internship at police headquarters, I selected an on-campus office at Christopher Newport University, where I earned my undergraduate degree a decade earlier. Through this position, I learned to write the annual budget for the grant, prepare quarterly reports, conduct evaluations, design surveys, build web pages, develop a leadership training curriculum, market programs, and learn the internal registration process, the state procurement process, and so forth. Applying these skills boosted my confidence and enhanced my professional development.

My direct supervisor had served in Vietnam and later retired from the Los Angeles Sheriff's Department with a comfortable pension and salary. He seemed out of place in an academic environment, particularly since he was from humble origins and worked in a blue-collar position most of his life. He was pragmatic, displayed a strong work ethic, and had a fabulous blue-collar sense of humor. His mission was to advance education and raise awareness of law enforcement as a profession. His assignment would soon clash with the university's reorientation. The school was reemphasizing liberal learning and wanted to attract more wealthy students from Northern Virginia. Faculty selection was increasingly confined to the more prestigious schools. Job applicants without proper academic pedigrees rarely got an interview.

Notwithstanding the changed environment, during those years several professors supported my intellectual growth. They encouraged me to teach as 
an adjunct, attend professional conferences, and participate in different research projects. One faculty member convinced me to pursue a $\mathrm{PhD}$ with this simple question: "What else are you going to do with your time?" I could think of many fun activities for a young single person, yet none was productive or offered the rewards I valued. Funny how such a straightforward inquiry could prove so profound for this daughter of a shipyard worker in deciding to pursue a doctorate.

After becoming a full-time instructor, and later an assistant professor, I really started feeling inferior because of my working-class background. As the culture of the university shifted, I felt I had nothing in common with the new hires or the entering freshmen. In addition, I was weary from working under the unstable circumstances of year-to-year contracts as a full-time instructor. I never knew whether my contract would be renewed, so I decided to search for a tenure-track position. I was still feeling out of place in academia when I accepted a tenuretrack position in Texas. I had an inferiority complex. I did not appreciate socalled high culture (the knowledge the academy considers "privileged") as much as I thought I should. Aside from Bolero, I did not listen to classical music. I had never taken a music appreciation course. I am more of a rock 'n' roll and blues kind of woman. While I appreciate Van Gogh and Dali, I cannot discuss the intricacies and eras of art and artists. Until I entered academia, my travels were limited to a trip to San Francisco as a photographer's assistant and journeys within reasonable driving distance from my home in Virginia - the mountains and beaches of North Carolina and occasional trips to Washington, D.C. My finances and work schedule never allowed me the luxury of travel, especially outside the country.

My inferiority complex was at its maximum in social settings with other academics, people whose knowledge of literature and classical music was far deeper than mine — not that that took much — and who had traveled "overseas." Aside from a yard-sale copy of Emily Post, I knew nothing about proper protocol and etiquette at parties, dinners, and conferences. I lacked the finesse of cocktail banter. I felt I had missed a proper education when faculty engaged in long-winded discussions on their narrow areas of expertise. It took me a while to figure out that no one is omniscient. It was emancipating learning to draw professors out of their narrow areas of expertise into conversations grounded in general knowledge. Eventually, I felt comfortable discussing "the right" topics I knew well.

\section{EMPOWERING STUDENTS}

I agreed to submit a narrative to this symposium because I saw it as an opportunity to illustrate the obstacles people from the working-class experience before, during, and after college. It takes an enormous amount of physical, emotional, and mental endurance for working-class students to enter college and complete their studies, let alone earn a doctorate. I will end this account 
by sharing what I have found helpful through my own experiences and offering suggestions for maximizing the potential of working-class, lower socioeconomic status, and first-generation college students.

\section{Empowerment through Storytelling}

Shift feelings of shame into feelings of empowerment. Students from humble origins must understand they are not alone in higher education, nor should they feel ashamed of their childhood circumstances and experiences. Some of these students grew up in neighborhoods where poverty, gang violence, and homicides are prevalent. It is miraculous they are alive, much less enrolled in college. Working-class students must learn to embrace their story of overcoming obstacles and use their origins as a source of empowerment; and we, as professors, must encourage them in this direction.

Today, there is "no shame in my game." I used to be embarrassed about my father's death from heroin addiction. Today I understand the disease of addiction, the institutional complexities, and the need for reform. I never shared his story until leaving my first academic position. I am extremely proud of my mother-she was in the first female cohort hired by the shipyard in the early 1970s. She still works in the yard. In my early academic career, whenever I felt like whining about my cold office in the summer, I would drive to the 50th Street gate on Washington Avenue and watch the shipyard laborers, particularly my mother, working at the most physically demanding job in the hottest part of summer.

Faculty members from humble origins should share their own stories and serve as role models for students of similar backgrounds. In my diversity management course, I ask students to summarize my background based on their first impressions. The most frequent response is that I, as a white, female professor, must be from a privileged family. I then use the students' observations to discuss stereotypes and the role of social class origins in determining life outcomes.

\section{Provide Professional Guidance}

Invest in students, especially those struggling financially, whatever their origins. It was painfully evident that one of my students was not reading the required materials for class. When I asked him about this, he said he could not afford the text. I likely would have found this excuse unacceptable during a regular semester, because financial aid is readily available. However, this was a summer class; so I asked him to explain. He volunteered information that proved his point. We scheduled a meeting in my office, where I lent him one of my extra copies of the text. At the time of this writing, he is scheduled to graduate in one semester. Even now, he thanks me for lending him the textbook. If I do not have that many extra texts for lending, I put books on reserve in the university library. Sometimes, I distribute free articles to students, which helps offset the high costs of many textbooks. 
Along these same lines, I encourage all students, but especially those of working-class origins whose parents probably never taught them about such things, to avail themselves of broader university resources, including the writing center and the career development office. I inform students of upcoming workshops and networking opportunities. I ask the university or certain student groups to host social etiquette dinners each semester at a convenient time so working-class students can attend, and then encourage everyone to go. I invite alumni to speak in classrooms. We offer a "backpack-to-briefcase" series at the University of Baltimore. The program matches alumni with particular courses and instructors and offers evidence of success along with inspiration to students who may be filled with self-doubt or experiencing any number of obstacles.

Faculty should emphasize the importance of networking through professional organizations such as the American Society for Public Administration (ASPA) and encourage students to get involved at the local, state, or national level of this organization. Push students to attend conferences hosted by various professional organizations. Volunteer to sponsor registration fees for the neediest students. Through conversations and other interactions, you will learn who most needs assistance, which is why it is important to foster rapport with all your students (see next suggestion). As a coordinator for the 2010 Social Equity Leadership Conference in Baltimore, I paid registration fees for several students. Most were from our university; however, a few graduate students from other institutions were interested in attending but could not afford it. The current fiscal crisis has resulted in reduced support for faculty, so it is no surprise that many universities have few resources to offer students. To their credit, Rutgers-Newark and Virginia Commonwealth universities provided extensive support for multiple student registrations to help those needing financial assistance. As faculty members, we have all been hurt by cutbacks in recent years; nevertheless, we must remind ourselves of the limited financial means of some students.

\section{Provide Personal Guidance}

Faculty must keep an open mind, an open heart, and retain the ability to listen genuinely to all students, but especially those whose problems may stem from being of humble origins. Sometimes these concerns extend beyond formal instruction. One of my former students was worried about finding housing for her mother. The student lived on campus. Her mom was about to be evicted from her home and needed immediate assistance. Being new to Texas and lacking a background in social work, I spent a good hour making phone calls and seeking potential sources of assistance. I like to believe most professors would do the same.

In contrast, I have also heard numerous excuses for late papers or less than stellar performance. It is not difficult to determine legitimate requests from lame 
excuses. A "trust but verify" policy is useful. House burnt down? There's likely to be a news report about the incident. Cousin was shot? It is in the crime report of the local paper. Power cut off? Show me the bills (students have done this). The information some students share displays their trust in me. Students affected by drug addiction in their own families sometimes confide in me. I am not a licensed therapist. I cannot solve their problems. However, I can relate to their challenges and I listen to their concerns. I can provide encouragement and link students to necessary resources.

\section{Increase Awareness}

Increase awareness of social class issues in the classroom and in the field. As teachers and scholars, we have a responsibility to critically examine assumptions about mobility and meritocracy. Students should be introduced to the concept and measures of social mobility. We must consider the effect of declining mobility on public administration in terms of falling revenues and increased demand for public services. We must understand the social and democratic implications of diminishing mobility within American society. I have attempted to increase awareness on issues of social class through conference presentations and publication. For example, I have authored or coauthored various articles, including "Social Class and Socioeconomic Status: Relevance and Inclusion in MPA/MPP Programs"; "The Enduring Myth of the American Dream: Mobility, Marginalization, and Hope"; "Blue-Collar Mother/White-Collar Daughter: A Perspective on U.S. Policies toward Working Mothers"; and "Diversity across the Curriculum: Perceptions and Practices." I have also participated in several panels that address issues of social class at conferences such as the National Academy of Public Administration Social Equity Leadership Conference, National Association of Schools of Public Affairs and Administration, Public Administration Theory Network, and Teaching PA.

Paradoxically, students from humble origins are often the strongest disciples of meritocracy because they became successful despite the odds against them. We cannot discount their hard work by suggesting meritocracy does not exist. Nor can we ignore the data showing that when it comes to college admissions, some students are more equal than others are. Instead, we must encourage all students to understand the profound effects our circumstances of birth, just like other major demographic categories, have on our lives.

Ideally, candidates chosen under a merit system are selected based on qualifications only. Realistically, "qualifications" derive from investments in social capital in the first place. We might refer to this problem as the commodification of merit. The quality of schools and after-school programs often reflects the socioeconomic status of neighborhoods. Some studies (Corcoran, Evans, Godwin, Murray, \& Schwab, 2004; Phillips \& Chin, 2004; Stringfield \& Yakimowski-Srebnick, 2005) have documented the disparities between children 
attending high-poverty schools compared to children attending low-poverty schools. The likelihood of admissions into the top universities is a reflection of access to social and financial capital. Children born into poverty are least likely to attend college. Fifty-three percent of children of the top fifth of income earners will finish college, compared to only $11 \%$ of those from the bottom income quintile (Eckholm, 2008). The children of top income earners are overrepresented at Ivy League institutions-they constituted 75\% of Harvard's freshmen class in 1999 (Raines \&McAdams, 2006). Similarly, only 3\% of freshmen among 146 selective colleges and universities in the United States represent families at the bottom quarter of the income distribution (Oldfield et al., 2006).

A blatant example of the commodification of merit is the legacy admission. The Chronicle of Higher Education has reported on legacy admissions for some time now. One can hardly argue that a meritorious system exists when students with average or below average grades are admitted to Ivy League institutions because their parents are alumni and/or large benefactors. In these instances, money and status buy access. We can pretend such decisions are based on merit, or we can counter such gross inequities by providing equal or special consideration to first-generation students.

\section{CLOSING REMARKS}

Legitimacy is warranted on issues of social class in the field of public administration. The National Association of Schools of Public Affairs and Administration (NASPAA) includes class as a social identity category in its definition of diversity. In addition, social class is relevant to social equity, particularly the harmful effects of increasing income inequality among Americans. Public administrators may offer "policy proposals to reduce social and economic problems ... to address the effects of discrimination based on personal characteristics or the restricted prospects produced by inadequate socioeconomic resources" (Svara \& Brunet, 2005, p. 254). Public administrators, particularly academics, should work to eliminate the barriers perpetuating classism in higher education, including raising awareness of inequities in the $\mathrm{K}-12$ public education system and proposing and studying innovative initiatives to level the playing field. As first-generation academics, we owe it to ourselves and our students.

\section{FoOTNOTE}

1 Although my mother never remarried, we resided with this individual for 9 years. 


\section{REFERENCES}

Aronowitz, S. (2004). Against schooling: Education and social class. Social Text, 22(2), 13-35.

Bordieu, P. (1989). The state nobility. Stanford, CA: Stanford University Press.

Corcoran, S., Evans, W. N., Godwin, J., Murray, S. E., \& Schwab, R. M. (2004). The changing distribution of education finance, 1972-1997. In K. M. Neckerman (Ed.), Social Inequality (pp. 433-465). New York: Russell Sage Foundation.

Clynch, E. J., \& Gaudin, C. A. (1982). Sex in the shipyards: An assessment of affirmative action policy. Public Administration Review, 42(2), 114-121.

Eckholm, E. (2008, February 19). Higher education gap may slow economic mobility. New York Times. Retrieved from www.nytimes.com/2008/02/20/us/20mobility.html?scp=1\&sq=Eckholm,\%20 E.\%20\%282008,\%20February\%2019\%29.\%20Higher\%20education\%20gap\%20may\%20 slow\%20economic\%20mobility.\%20New\%20York\%20Times\&st=cse

Oldfield, K, Candler, G. \& Johnson, R. G. (2006). Social class, sexual orientation, and toward proactive social equity scholarship. American Review of Public Administration, 36(2), 156-172.

Phillips, M., \& Chin, T. (2004). School inequality: What do we know? In K. M. Neckerman (Ed.), Social Inequality (pp. 467-519). New York: Russell Sage Foundation.

Raines, J., \& McAdams, C. B. (2006). College and social class: The broken promise of America. Cross Currents, 56(1). Retrieved from www.crosscurrents.org/Rainesspring2006.htm

Stringfield, S. C., \& Yakimowski-Srebnick, M. E. (2005). Promise, progress, problems, and paradoxes of three phases of accountability: A longitudinal case study of the Baltimore City public schools. American Educational Research Journal, 42(1), 43-75.

Svara, J. H., \& Brunet, J. R. (2005). Social equity is the pillar of public administration. Journal of Public Affairs Education, 11(3), 253-258.

Heather Wyatt-Nichol is the MPA program director in the College of Public Affairs at the University of Baltimore. She earned a PhD in Public Policy and Administration from Virginia Commonwealth University and an MPA degree from Old Dominion University. She has published book chapters and articles on a variety of topics in public administration and feminist journals. Her research interests include diversity management, ethics, family friendly-workplace policies, organizational behavior, and social equity. 